\title{
A contribution to global sustainable development: inclusion of microalgae and their biomass in production and bio cycles
}

\author{
Armen B. Avagyan
}

Published online: 27 August 2008

(C) Springer-Verlag 2008

\section{Introduction}

Progress in scientific knowledge and its application via industrial products creates new hope of improved living standards. However, this progress also gives rise to additional questions, concerns, and even opposition, at times violent, from citizens or opinion leaders. There are many different groups and communities, which do not always trust or listen to each other, rendering dialogue difficult. The positions of each are undeniably legitimate and respectable, but take little account of the additional perspectives of a multi-dimensional reality. I suggest that the knowledge-based bio-economy will play an important role in the emerging reality. Past 'green' revolutions have required substantial external inputs, such as chemical fertilizers and pesticides. While technology has provided yield increases, this was not sustainable in the long term. Some technological improvements have reduced production risk, while others have increased it. Furthermore, the effects of technological change on production risk have varied over time, space, and production activities. Some of these side effects have been detrimental to individual and public welfare (WDR 2008). For example, while increases in the use of fertilizers like nitrogen have had a positive impact on agricultural production, they have also had notable negative effects on human and environmental health (Pardey

\footnotetext{
A. B. Avagyan ( $\square)$

Research and Industry Centre of Photosynthesizing Organisms, Feed Additives and Physiologically Active Compounds, Yerevan 0025, Armenia

e-mail: arminaav@freenet.am; avagyan_armen@yahoo.com
}

et al. 2008). Furthermore, the effect of technological change in agriculture extends beyond improvements in the quantity and quality of agricultural output. Nongovernmental organisations have criticized the reliance on green revolution technologies, as they are believed to be environmentally unsustainable and discriminatory to resource-poor farmers. Environmental groups such as Greenpeace have opposed the introduction of biotech crops. At the same time, climate change is expected to have far-reaching implications for agriculture that will disproportionately affect the poor (WDR 2008). Greater risks of crop failures and livestock deaths are already imposing economic losses and undermining food security and they are likely to get far more severe as global warming continues (IFAD 2007; WDR 2008). Five main climate change factors are predicted to affect agricultural productivity: changes in temperature, precipitation, $\mathrm{CO}_{2}$ fertilization, climate variability, and surface water runoff. Adaptation measures are needed urgently to reduce the adverse impacts of climate change, as well as to minimize the costs of natural disasters. Acceleration of sustainable development requires the implementation of adaptation and mitigation measures.

Two broad conclusions can be drawn regarding technological change in agriculture and its effect on production, health, and environmental risk. Technological change has increased the quantity of agricultural products, but it has also had varied effects on production risk (Pardey et al. 2008). Fostering access to improved technologies should thus be a key objective for policies aimed at helping farmers manages production risk.

Consequently, as a contribution to global sustainable development I propose below that greater use should be made of microalgae and their biomass in more sustainable agricultural production. 


\section{Global challenges of agriculture sustainable development: the role of microalgae}

A major global challenge faced today is the increasing price of food, feed associated, in part at least, with alternative uses of food, and feed crops in biofuel production. Moreover, the capacity of grain-based biofuels to replace fossil fuels, particularly for transport, is believed to be extremely limited (Global Fuels Magazine 2007). To shift to biofuels in a managed fashion, which is the professed policy of governments, and then a strong agriculture sector must be developed that is both productive and environment-friendly. The demand for grain will increase further as the world's population grows ( 9 billion in 2050, compared with 6.5 billion in 2006) and grain consumption in developing countries is expected to double by 2050 from an annual average of 1.1 billion tons between 1999 and 2001 (IFAD 2007). Interest in the use of biomass as a fuel or energy source has been increasing because of climate change and energy efficiency policy and issues (Avagyan 2008a). The USA has accelerated the development of renewable energy and reductions in greenhouse gas emissions (USDA 2003; Duesterberg 2007). US Government policy highlights the need for the biomass industry to develop new feedstocks, which will be easier to grow, produce higher yields of biomass, and be efficiently processed into fuel, power, and products that will help both technology developers and investors to identify viable applications of biomass (including alga) for fuels, power or products (Roadmap for Bioenergy and Biobased Products in the US 2007). Incentives will be needed to encourage capital investment in biorefineries as well as in scale-up and the construction of demonstration facilities.

EU energy policy targets include developing renewable sources to provide $20 \%$ of all energy by 2020 and for biofuel to grow to become $10 \%$ of fuel use.

Algae have emerged as one of the most promising sources especially for biodiesel production (Avagyan 2008a). Yields of oil from algae are orders of magnitude higher than those from traditional oilseeds (Sheehan et al. 2006, Table 1 by Riesing 2007). In addition, algae can be grown away from farmlands and forests, thus minimizing the damage caused to the ecosystem and the conventional food chain. They can be harvested very quickly, speeding the production process dramatically. Furthermore, algae have properties that make commercial production attractive, such as faster growth compared with land-grown plants; uniform cell structure with no bark, stems, branches or leaves, allowing easier extraction of products and higher utilization of microalgae cells; cellular uniformity making practical the manipulation and control of growing conditions for the optimization of cell properties. The production of microalgal biomass may be beneficial to countries not
Table 1 Yield of bio-oils produced from a variety of crops

\begin{tabular}{ll}
\hline Substance & Gallons of oil per acre per year \\
\hline Corn & 15 \\
Soybeans & 48 \\
Sunflower & 102 \\
Rapeseed (canola) & 127 \\
Oil palm & 635 \\
Microalgae & \\
Based on actual biomass yields; & 1,850 \\
Theoretical laboratory yield & $5,000-15,000$ \\
\hline
\end{tabular}

capable of growing conventional crops. Biofuel production could well be a new rapidly growing global market for algae products (Avagyan 2008a). Many companies [Chevron (Chevron 2007), Petro Sun Drilling (LeCrone 2008), Royal Dutch Shell (Sweeney 2007)] are reviewing their energy policies and strategies to comply with today's legislative and economic drivers and are diversifying their businesses to use liquid transportation fuels produced from algae. In addition, the rise in oil prices increase the cost of both fossil-feedstock derived chemicals and biotechnological fermentation products used in agriculture. I suggest, therefore, that microalgae biomass, capturing solar energy by photosynthesis, can develop into an alternative source of important feedstocks (Avagyan 2008a).

Other global challenge appears to be the quality of food and feed. Compared with 50 years ago, today's fruits and vegetables contain reduced amounts of key nutrients, including proteins (by 6\%), calcium, phosphorus, iron, vitamin $\mathrm{B}_{2}$ (by $38 \%$ ) and vitamin $\mathrm{C}$, according to recent findings (Davis et al 2004). Although there is probably more than one explanation, the trend may arise from farmers aiming to generate high crop yields. Product quality impairment and a decrease in animal resistance to disease may have arisen from attempts to increase feed assimilability, achieved principally by using small concentrations of physiologically active compounds (PAC) and adding enzymes, that raised the degree of cellulose hydrolysis, assimilability and the weight of production per feed unit. As a result, there has been an increased need, for both people and animals, to use food additives to compensate for a lack of PACs (Avagyan 2008b). By comparison, microalgae accumulate up to $50-70 \%$ of protein (cf. up to $50 \%$ in meat and up to $15-17 \%$ in wheat), $30 \%$ of lipids, over $40 \%$ of glycerol, up to $8-10 \%$ of carotene and relatively higher concentration of vitamins $B_{1}$, $\mathrm{B}_{2}, \mathrm{~B}_{3}, \mathrm{~B}_{6}, \mathrm{~B}_{12}, \mathrm{E}, \mathrm{K}$ and $\mathrm{D}$, compared with biomass of plant or animal origin. Specifically, when feeding animals, poultry and fish using microalgae feed additives, we saw weight gains, enhanced production of milk and eggs and a decreased rate of mortality (Avagyan 2008b). 
A further problem faced today concerns the consequences caused by the over-use of antibiotics in feed. While antibiotics were proven to be effective in improving poultry production, their use came under pressure as an increasing number of consumers feared that their inclusion in animal feed would lead to antibiotic resistant bacteria that are pathogenic to humans. In 2005, the EU removed the last antibiotic growth promoters from pig and poultry diets, and the search for alternatives to these additives continues to attract intense interest. As a consensus begins to develop in the scientific community on this subject, a few approaches stand out in terms of efficacy and technological and economical feasibility. The use of organic acids and essential oils in the feed industry, while effective and economical, can potentially be a source of a variety of problems (Indresh 2007). The use of Chlorella as a feed additive can overcome problems concerning the use of antibiotics and organic acids in feed (Avagyan 2008b), since microalgae that have existed for billions of years contain natural organic acids that reduce colonization of pathogens (Avagyan 1993). Thanks to this feature, Chlorella can also be used for feed preservation (Muzafarov and Taubaev 1984). Hence, the successful application of a biomass-from-microalgae strategy may help to reduce not only general nutritional deficiency, but also counter the poor quality and inferiority of the majority of feed additives. The poultry potential demand for microalgae powder (as feed additives) is 880 tons in the Armenian domestic market, over 2.4 billon tons in USA, above 7 million tons in China, based on our local market calculations.

During microalgae aeration, $\mathrm{CO}_{2}$ is turned into $\mathrm{O}_{2}$ via photosynthesis that mitigates industrial emissions of $\mathrm{CO}_{2}$. Algae have been grown on the flue gases from an MIT cogeneration plant and algal crops harvested daily and are reported to reduce $\mathrm{NO}_{\mathrm{x}}$ by up to $86 \%$ and the $\mathrm{CO}_{2}$ by $40 \%$ of the smokestack emissions (Danielo 2005). The exhaust steam and effluent gas (including greenhouse emissions) may be used for heating microalgae suspension in pools so biomass manufacture may be available year-round. At the same time, it has been reported (Muzafarov and Taubaev 1984) that irrigation of growing wheat or rice by microalgae suspension produces a number of benefits. Processing seeds prior to sowing by treating with a microalgae suspension also increases their field germination rate and crop yield (Muzafarov and Taubaev 1984).

\section{Suggested global strategy for sustainable development}

The use of microbiological active slime and alga stands out as most effective and economically efficient method for the purification of industrial wastewater (Avagyan 2008c). However, bacteria of the active slime have low stability towards high concentrations of organic and mineral components. This method also requires subsequent destruction of excess active slime, which contains pathogenic microorganisms. Microalgae, on the other hand, possess higher stability, which enables their use in more concentrated and toxic environments. Sewage sludge has, unsurprisingly, proved a problematic material for environmental law and policy. The issue of how best to dispose of it, or still better, make some beneficial use of it, remains a matter of debate. Before 1998, sludge was mainly disposed of at sea, to agricultural land as fertilizer, incinerated or land filled. In 1998, disposal at sea was banned, and carefully regulated agricultural use became the principal method of disposal. At the same time, it is known that active slime contains very pathogen microorganisms, such as E. coli, that prohibit the use of biologically active waste in agriculture. Traditionally, incineration is considered the next alternative for disposal. However, this approach has encountered high levels of resistance in many countries at the planning and permitting stage. The EU Landfill Directive orders the reduction of the amount of waste sent for disposal in landfill. The directive requires that progressively increasing quantities of biologically active waste be diverted away from landfill. As land filling is clearly becoming a less acceptable waste management solution, the co-processing of waste will become even more attractive in the future. Maybe the Landfill Directive can become the main driver for the production of fuel-fraction active slime? Biogas can be efficiently generated from the anaerobic digestion of sewage sludge. In this multistage anaerobic process complex organic matter converts ultimately to $\mathrm{CO}_{2}(35 \%)$ and methane $(65 \%)$. However, there is a complex technological process, which makes monitoring complicated (Bennett 2007). This has opened the possibility of alternative approaches (Avagyan 2008a). From 1978 to 1996, the US Department of Energy's Office of Fuels Development (OFD) funded a program to develop renewable biodiesel from algae, known as the Aquatic Species Program (ASP) (Sheehan et al. 1998). The focus of this program was the production of biodiesel from high lipid-content algae. A major conclusion from these analyses is that, for microalgae production, there is little prospect for any alternatives to the open pool designs, given the low cost requirements associated with fuel production. The factors that most influence cost are biological- and not engineering-related. These analyses point to the need for highly productive organisms capable of near-theoretical levels of conversion of sunlight to biomass. Two hundred thousand hectares (less than $0.1 \%$ of climatically suitable land areas in the USA) could produce one quad $\left(1.055 \times 10^{18} \mathrm{~J}\right)$ of fuel. The DOE-ASP program concluded that the only plausible near- to mid-term application of microalgae biofuels production requires its integration with wastewater treatment. 
The international price set for the principal microalgae products varies from 31 to $\$ 200$ per $\mathrm{kg}$ (Avagyan 2008c). Our Center has planned to develop innovative technologies for microalgae manufacture with low cost production to promote global market access to farmers and biofuel producers. This would fulfil the main task of ASP and permit the cost-effective technology for microalgae production to be applied around the globe, thus assisting in the resolution of some of the global challenges that face the world community. The key aim of our R\&D has been to find solutions to these challenges, with the Center carrying out research to develop microalgae cultivation technologies in wastewaters from production of amino acids, [such as lysine (Avagyan et al. 1993)], other chemicals and chloroprene rubber production (Avagyan 1991, 1993) as well as from wastewaters of the enzyme and food industries. High levels of wastewater purification from organic and mineral compounds were achieved and a sharp reduction of the bacteria content in microbiologically infected wastewater (Avagyan et al. 1993) was observed. To exclude the application of costly mineral fertilizers, in parallel with the ASP, we developed a cost-effective technology with new approaches to various stages of microalgae production, including the nutrition of microalgae by organics present in industrial wastewater (though which is free of heavy metals and radioisotopes). The production has operated at full capacity for 3 months. Our business plan for this project is currently at the commercialization stage. The success of this project should reduce financial risk substantially to those seeking to invest microalgae production in the future when microalgae will find their beneficial application in food, feed and biofuel global markets.

\section{Conclusion}

Changes in technology drive economic growth in developing countries and contribute significantly to economic well-being in rich countries. A future climate treaty will need a better incentive structure to encourage full participation and compliance. Our strategy will allow the production of microalgae through the use and purification of wastewaters, which may be an additional source of profit, with no changes in tax law or subsidies for environmental protection. It will also help producers to gain additional profit and find optimum ways to generate raw material for biofuel production and to increase the quantity and quality of agricultural end- products. This should, as a consequence, improve the basic quality of farmers' products, making them more safe and attractive to buyers, as well as to produce high-quality feed and to reduce disease and poverty. In addition, these measures should help to reduce $\mathrm{CO}_{2}$ emissions, the cost of feed, waste production and the use of nitrogen fertilizers, increasing, as well, the $\mathrm{O}_{2}$ content in atmosphere, food quality and its competitiveness in the market. As a result, our quality of life and health could be improved. Including microalgae and their biomass in industrial manufacturing (such as wastewater treatment and biofuel production) and bio cycles (through including in food, feed and perfumery additives productions and irrigation system) will be one answer to unsustainable technological developments and climate change. It is possible that, in the near future, the abovementioned problems will be better perceived, leading to a global reorientation of priorities for sustainable development policy aimed at the promotion of global expansion of microalgae production.

Algae have been the major tool of life development on the globe and at present can be seen as major producers of atmosphere oxygen as well as natural cleaners of the world ocean waters. It is the choice of the Nature and our Centre.

\section{References}

Avagyan AB (1991) Research of chemical compound contents in wastewater of the Yerevan Factory of Chemical Reagents and microalgae culture selection aimed to wastewater purification. Report on contract 2/91-93 Yerevan Factory of Chemical Reagents. Confidentially. Yerevan: R\&I Center of FO, FA and PAC, p 34

Avagyan AB (1993) Development of "Nairit" factory wastewater cleaning technology by using microalgae. Confidential report on contract N 21 of Ministries of Industry of RA. Yerevan: R\&I Center of FO, FA and PAC, p 15

Avagyan A (2008a) Global prospects for microalgae production for biofuels and for the preservation of nature. Global Fuel Magazine, February: 22-27; http://www.propubs.com/global-fuels/ eGF_Feb08_LowRes.pdf

Avagyan A (2008b) Microalgae: big feed potential in a small package. Feed International, 29 (2): 16-18; http://www.fi-digital.com/ fi/200803/data/feedinternational200803-win32.zip. Microalgae hold promise as antibiotic alternative. Feed Formulator, 2008, February; http://www.feedindustrynetwork.com/ViewContent. aspx ?id=24990)

Avagyan A (2008c) Microalgae production development global prospects and profitable technology wasterwater purification by the use microalgae. Water and Wastewater International, 24(4) (in press)

Avagyan AB, Arshakyan GG, Paronyan RV, Avagyan SA, Matevosyan MM, Gyulumyan EA (1993) Feasibility of purification sorption effluent from ion exchange lysine production with uses chlorella. Appl Biochem Microbiol 29(3):723-727

Bennett A (2007) Wastewater treatment and energy production. Filtration and Separation, December: 16-19

Chevron (2007) Chevron and National Renewable Energy Laboratory to Collaborate on Research to produce transportation fuels using algae; http://www.chevron.com/news/press/release/?id=200710-31; http://www.greencarcongress.com/2007/10/chevron-andnre.html

Danielo O (2005) Biofutur, 255; http://www.greenfuelonline.com/ news/algaefuel.pdf

Davis DR, Epp MD, Riordan HD (2004) Changes in USDA food composition data for 43 garden crops, 1950 to 1999. J Am Coll Nutr 23(6):669-682 
Duesterberg TJ (2007) What the new Congress has in store for manufacturing. Industry Week News 256(1):6

IFAD (2007); http://www.ifad.org/climate/factsheet/e.pdf

Indresh HC (2007) Organic acids, plant extracts can be effective choice for antibiotic alternative. Feed Int 28(8):10-12

Global Fuels Magazine (2007) Global industrial energy review, February, p 11

LeCrone J (2008) PetroSun: why algae-to-biofuels? Why not now? http://biz.yahoo.com/iw/080407/0384196.html, http://biz.yahoo. com/iw/080324/0378475.html; http://www.petrosuninc.com/algae-biofuels.html

Muzafarov AM, Taubaev TT (1984) Cultivation and application of microalgae. Tashkent: FAN, p 133

Pardey P, James J, Alston J, Wood S, Koo B, Binenbaum E, Hurley T, Glewwe P (2008) Science, technology and skills; http://www. harvestchoice.org/documents/hcpubs/Pardey\%20et $\% 20 \mathrm{al} \%$ 20WDR2008\%20Background\%20Paper-ALL1.pdf

Riesing TF (2007) Cultivating algae for liquid fuel production; http://oakhavenpc.org/cultivating_algae.htm

Roadmap for Bioenergy and Biobased Products in the United States (2007) Biomass Research and Development Technical Advisory Committee \& Biomass Research and Development Initiative, http://www.biomass.govtools.us; http://www.brdisolutions.com/ Site\%20Docs/Roadmap/OBP_roadmapv2_web.pdf

Sheehan J, Dunahay T, Benemann J, Roessler P (2006) A Look Back at the US Department of Energy's Aquatic Species Program: Biodiesel from Algae, http://www1.eere.energy.gov/biomass/ pdfs/biodiesel_from_algae.pdf
Sweeney G (2007) Shell and HR Biopetroleum Form Joint Venture for Algal Biofuel Production; http://www.greencarcongress. com/2007/12/shell-and-hr-bi.html

USDA (2003) USDA Targeted Incentives for Greenhouse Gas Sequestration; http://www.usda.gov/news/releases/2003/06/fs-0194.html

WDR (2008) Adaptation to and mitigation of climate change in agriculture; http://siteresources.worldbank.org/INTWDR2008/ Resources/2795087-1192112387976/WDR08_15_Focus_F.pdf

\section{Author Biography}

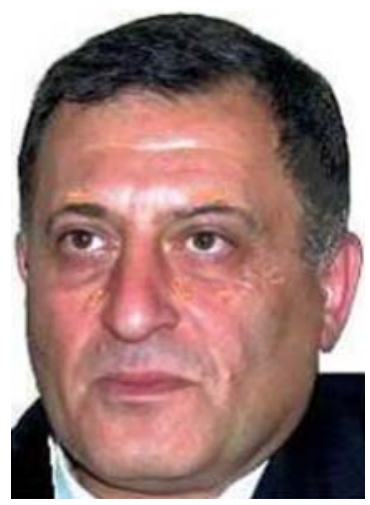

Dr. Armen B. Avagyan is the President of the Research and Industry Centre of Photosynthesizing Organisms, Feed Additives and Physiologically Active Compounds and Deputy Director of Nairit JOC. He worked also as Director of the Yeravan Vitamin Plant and Armenian Institute of Biotechnology. He is also an Expert Member of the Council of Chemistry and Petrochemistry of the CIS Countries and for INTAS and the 7th Framework Programme of the EU. 